\title{
Kajian Karakteristik Permukiman Kumuh Kampung Pekojan Semarang
}

\author{
Wahjoerini, Iryan Dwi Handayani \\ Program Studi Perencanaan Wilayah dan Kota, Fakultas Teknik Universitas Semarang \\ wahjoerini@usm.ac.id
}

INFO ARTIKEL
Riwayat Artikel:
Diterima: 16-07-2020
Disetujui: 01-08-2020

Kata Kunci:

Permukiman

Kawasan Kumuh

Kampung Kota

Kampung Pekojan

\begin{abstract}
ABSTRAK
Abstrak: Perkembangan penduduk dan perekonomian di Jawa Tengah khususnya di Kota Semarang dewasa ini sangat pesat. Hal ini disebabkan karena letak Akulturasi budaya ini terjadi karena perbedaan karakteristik masing-masing penduduk yang tinggaldalam satu wilayah tertentu. Kampung Pekojan merupakan salah satu kampung di Kota Semarang yang memiliki karakter akulturasi budaya yang beragam tersebut. Lokasi Kampung Pekojan berada di Kelurahan Purwodinatan, Kecamatan Semarang Tengah, terbentang dari Jl. Agus Salim kearah selatan dengan batas Kali Semarang. Kampung Pekojan memiliki 3 etnis yang tinggal dalam satu kampung yaitu Cina, Koja, dan Jawa. Karakteristik budaya yang ada di Kampung Pekojan ini menarik untuk dijadikan objek penelitian karena memiliki keunikan seperti bangunan yang masih mempertahankan bentuk aslinya maupun penghuninya yang berasal dari berbagai etnis. Di sisi lain, Kampung Pekojan menghadapi pemasalahan yang cukup kompleks seiring dengan perkembangan Kota dengan adanya kawasan kumuh di kampung tersebut. Penelitian ini bertujuan untuk mengetahui karakteristik permukiman kumuh yang ada di Kampung Pekojan. Selain karakteristik, peneliti juga ingin melihat tingkat kekumuhan Kampung Pekojan. Analisis yang dilakukan yaitu dengan membuat kategori kawasan kumuh melalui metode skoring berdasarkan pada panduan atau pedoman identifikasi permukiman kumuh. Penelitian yang dilakukan akan menghasilkan karakteristik pemukiman kumuh di Kampung Pekojan serta tingkat kekumuhannya.
\end{abstract}

\begin{abstract}
The development of the population and economy in Central Java, especially in Semarang today is very rapid. This cultural acculturation occurs because of the characteristic differences of each resident in a particular region. Kampung Pekojan is one of the villages in Semarang which has a character of diverse cultural acculturation. Kampung Pekojan located in Purwodinatan Village, Semarang Tengah District, stretching from Jl. Agus Salim to the south with the border of Kali Semarang. Kampung Pekojan has three ethnic groups living in one village, namely China, Koja, and Java. Cultural characteristics that exist in Kampung Pekojan is interesting to be a research object because it has a uniqueness such as buildings that still retain its original form and its inhabitants derived from various ethnicities.

On the other hand, Pekojan Village faced quite complex problems along with the development of the City with the existence of slums in the village. This research aims to determine the characteristics of the slum in the Kampung Pekojan. In addition to the traits, researchers also want to see the level of slums of the Kampung Pekojan. The analysis was by creating slum categories through the scoring method based on a guide or a slum identification guideline. The research conducted will produce the characteristic of slums in Pekojan village as well as the level of its severity.
\end{abstract}

\section{A. LATAR BELAKANG}

Kampung kota merupakan suatu daerah yang memiliki kepadatan penduduk tinggi dan masyarakatnya masih memiliki kebiasaan tradisional. Selain dilihat dari karakteristik penduduknya, kampung kota juga masih memiliki kondisi sarana prasarana yang belum memenuhi kebutuhan masing-masing masyarakatnya, bangunan yang ada di Kampung Pekojan masih ada yang memiliki bangunan asli. Kepadatan penduduk di Kampung Pekojan sedikit demi sedikit menimbulkan permasalahan yang berkaitan dengan lingkungan dan kondisi ekonomi penduduknya. Permasalahan lingkungan dapat dilihat dari kondisi air bersih, MCK dan saluran drainase yang masih belum memenuhi kebutuhan. Sedangkan untuk permasalahan ekonomi dapat dilihat dari penghasilan sebagian besar masyarakat yang masih tergolong rendah. Meskipun kondisi lingkungan yang masih tergolong kurang dan kondisi ekonomi yang masih rendah, masyarakat Kampung pekojan memilih menetap untuk tinggal di sana. Eksistensi kampung kota sebagai pemukiman yang berdiri sendiri dibangun dengan kekuatan penduduknya memiliki kemampuan untuk mempertahankan nilai- 
nilai kemanusiaan dalam kehidupan perkotaan modern (Putra, 2013). Sedangkan menurut (Setiawan), eksistensi kampung memiliki arti yaitu kemampuan untuk mempertahankan bentuk fisik, fungsi dan budaya yang ada di dalamnya. Kelangsungan hidup dilihat berdasarkan kemampuan dalam menjaga eksistensinya. Setiap kampung memiliki keunikan karena kampung mempresentasikan kekhasan sejarah. Namun menurut Soetomo, kampung sebagai permukiman pemerintah tidak hanya memberikan arti terhadap identitas perkotaan, namun juga memberikan dampak kehidupan sosial ekonomi bagi penduduk perkotaan.

Kota Semarang masih memiliki kampung kota dengan karakteristik beragam dilihat dari berbagai macam etnis yaitu etnis Cina, Koja dan Jawa. Kondisi sosial di Kampung Pekojan memiliki interaksi sosialyang tinggi. Perbedaan etnis tidak menimbulkan masalah bagi masyarakat kampung Pekojan. Sedangkan untuk kondisi ekonomi, kebanyakan dari mereka memiliki mata pencaharian sebagai pedagang, dapat dilihat dari adanya ruko di sepanjang Jl.Pekojan yang didominasi oleh etnis Cina dan Arab. Selain untuk perdagangan, di dalamnya di dominasi oleh permukiman. Kepadatan penduduk menyebabkan meningkatnya kebutuhan akan ruang untuk tempat tinggal. Kebutuhan akan tempat tinggal membuat kampung Pekojan memiliki lingkungan yang kurang nyaman karena pembangunan yang tidak disertai dengan pengendalian yang baik. Pembanguanan tanpa pengendalian akan membuat lingkungan menjadi tidak tertata dan berdampak kumuh. Dari uraian diatas, maka penulis akan melakukan penelitian tentang karakteristik permukiman kumuh Kampung Pekojan Semarang serta tingkat kekumuhannya.

\section{B. METODE PENELITIAN}

Dalam penelitian ini adalah jenis penelitian yang digunakan yaitu kuantitatif deskripstif. Penelitian kuantitatif adalah penelitian dengan memperoleh data yang berbentuk angka atau data kualitatif yang diangkakan. Tingkat kekumuhan ini dilakukan dengan mengkategorikan kawasan kampung kota melalui metode skoring berdasarkan panduan identifikasi permukiman kumuh.

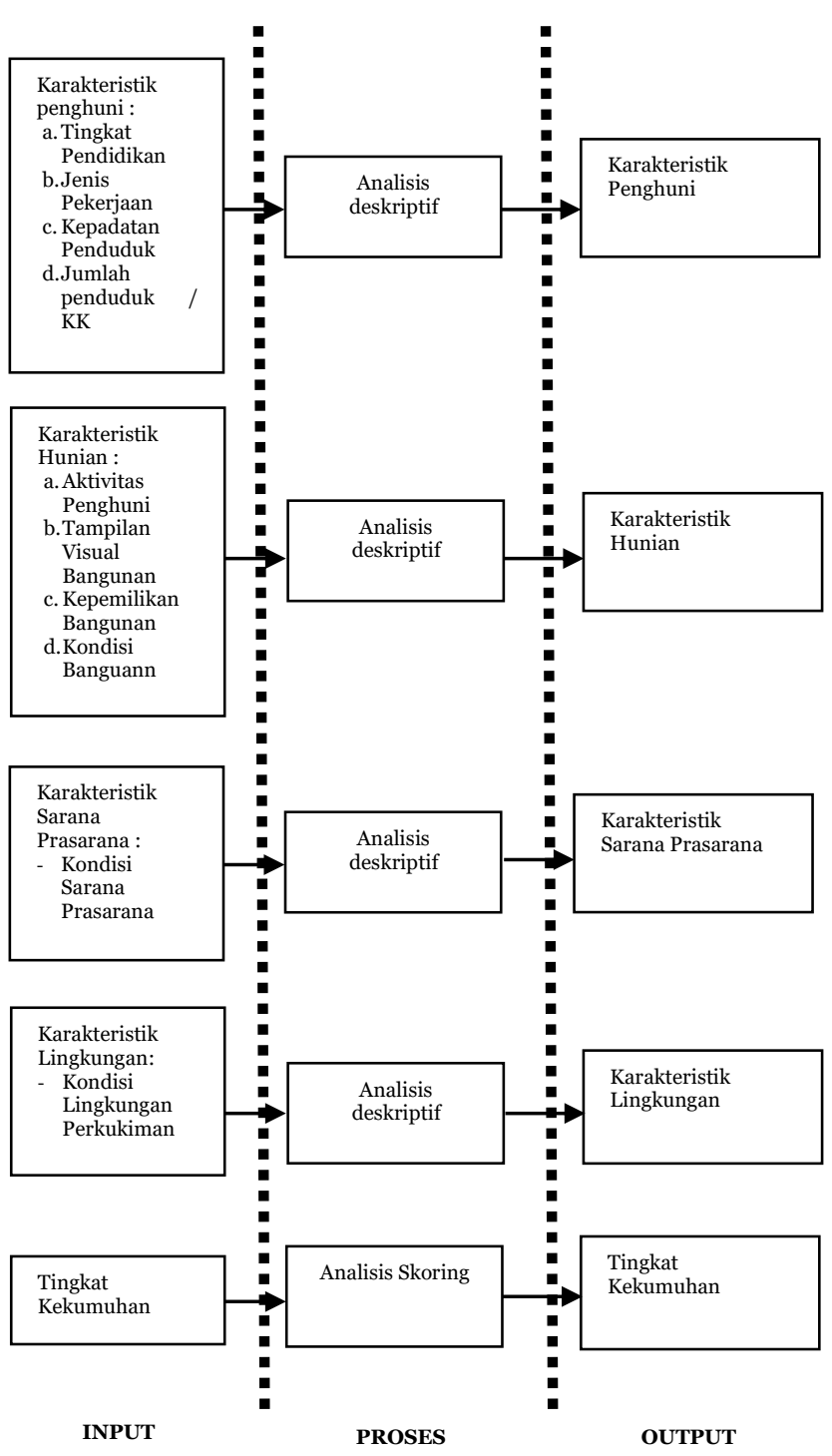

Gambar 1. Kategori kawasan kampung kota

\section{HASIL DAN PEMBAHASAN}

\section{Karakteristik Penghuni}

Kampung Pekojan memiliki jumlah penduduk 1.257 jiwa. Berdasarkan data monografi kelurahan Purwodinatan, jumlah penduduk kampung Pekojan pada tahun 2018 yaitu 1.257 jiwa. Penduduk Kampung Pekojan terdiri dari penduduk pribumi, selain itu penduduk kampung merupakan warga negara indonesia keturunan asing yaitu RRC (Republik Rakyat Cina) dan keturunan koja. Ada 80\% dari jumlah penduduk kampung Pekojan merupakan keturunan koja dan pribumi yang 50\% nya terdiri dari etnis koja sedangkan 20\% merupakan keturunan cina.

\section{Karakteristik Hunian}

Bangunan arsitektur etnis cina menempati jalan raya kampung Pekojan yang sekarang ini hanya ditempati oleh orang-orang etnis Cina yang tinggal di pekojan. Bangunan arsitektur Cina ini pada sekarang ini banyak digunakan untuk ruko. Bangunan Cina di kampung Pekojan ini bercirikan pada atap bangunan terdapat tulisan Cina. Biasanya bangunan cina itu berupa dua lantai karena sekaligus digunakan untuk tempat tinggal. Di kampung Pekojan ini, pada bangunan arsitektur Cina di salah satu bangunannya tedapat tulisan Cina yang dipercaya untuk mengusir roh halus. 

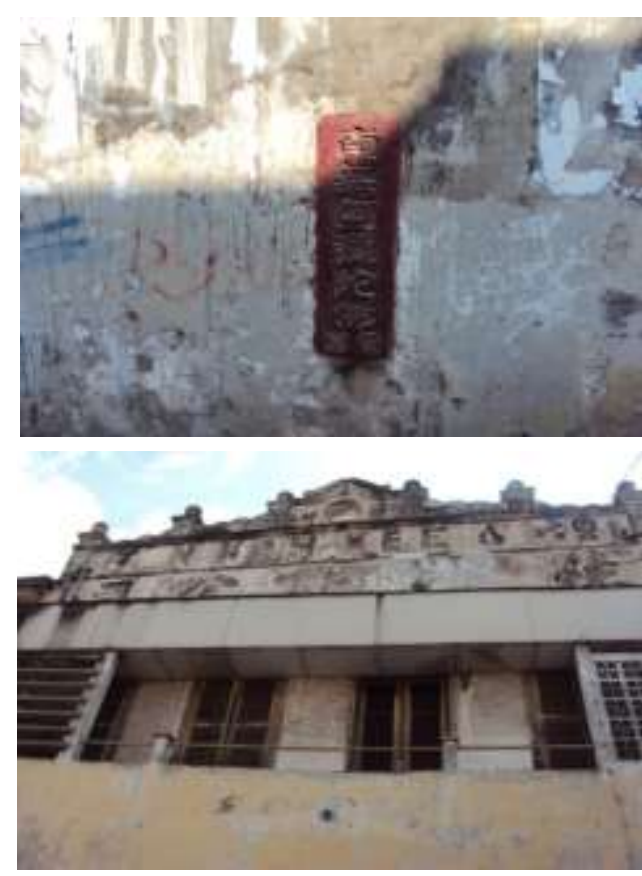

Gambar 2. Bangunan Etnis Cina

Di kampung Pekojan, bangunan arsitektur arab yaitu masjid Jami’ Pekojan. Kampung Pekojan memliki bangunan arsitektur arab yang bisanya digunakan untuk kegiatan-kegiatan yang berlangsung di kampung ini, seperti terlihat pada bangunan masjid Jami' Pekojan Semarang yang sekarang ini mengalami perubahan dimana bangunan tersebut menjadi lebih besar.

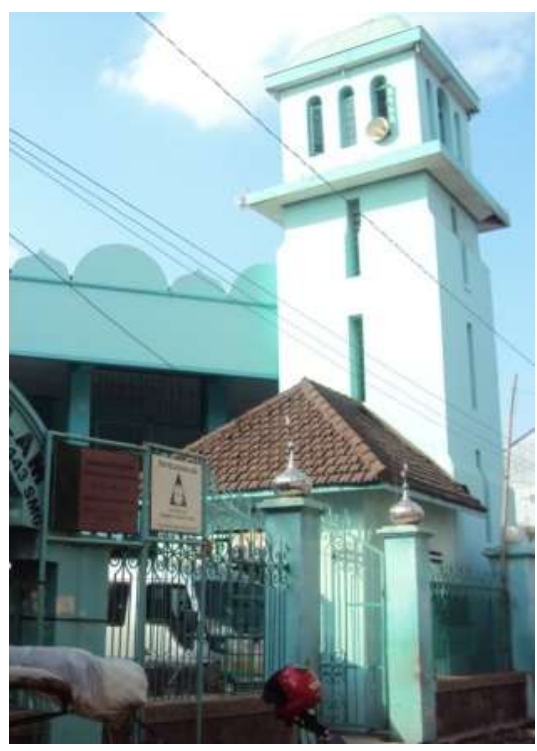

Gambar 3. Bangunan Arsitektur Arab

Bangunan-bangunan jawa ini masih bisa ditemukan di bagian dalam kampung Pekojan. Bangunan yang masih mampu bertahan ini berada di dalamnya tidak berada pada jalan yang merupakan faktor penyebab bangunan-bangunan berubah menjadi arah perdagangan yang saat ini berganti sebagai rukoruko.

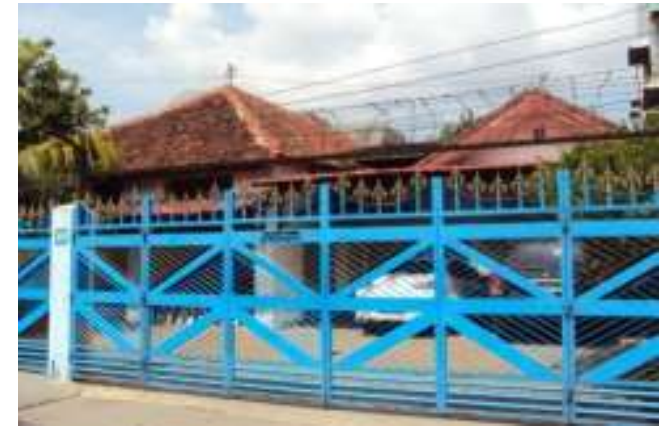

Gambar 4. Bangunan Arsitektur Jawa

\section{Karakteristik Sarana Prasarana}

Kondisi sarana prasarana di Kampung Pekojan yang merupakan RW III Kelurahan Purwodinatan, sebagian besar kebutuhan sarana dan prasarana belum terpenuhi, baik untuk jaringan drainase maupun tingkat pelayanan air bersih dan sanitasi.

\section{Karakteristik Lingkungan}

Kampung Pekojan memiliki lokasi yang bersebelahan dengan kali Semarang. Hal ini membuat kondisi lingkungan di Kampung Pekojan terlihat kumuh dan tidak terawat. Tidak adanya prasarana yang memadai dikampung ini membuat kampung memiliki lingkungan yang tidak sehat seperti misalnya air bersih.

\section{Karakteristik Tingkat Kekumuhan}

Peneliti melakukan survey dengan total 91 responden pada Kampung Pekojan Semarang untuk mengetahui karakteristik permukiman kumuh kampung Pekojan. Berdasarkan hasil skoring, total nilai skoring yaitu 61\% sehingga Kampung Pekojan Semarang dikategorikan dalam tingkat kekumuhan sedang.

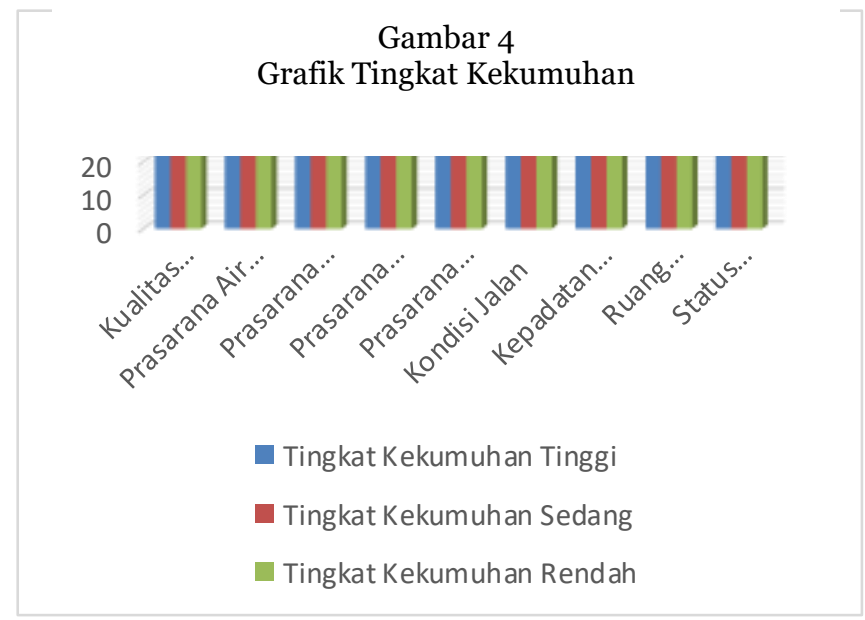

Gambar 5. Grafik tingkat kekumuhan 


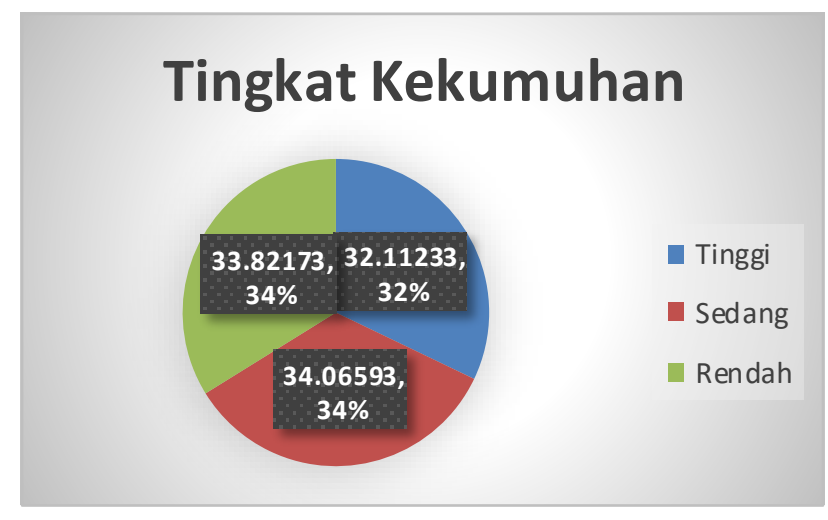

Gambar 6. Diagram tingkat kekumuhan

\section{SIMPULAN DAN SARAN}

Berdasarkan dari penelitian yang telah dilakukan, Kampung Pekojan memiliki tingkat kekumuhan dalam kategori sedang. Hal ini ditunjukkan dengan beberapa karakteristik Kampung Pekojan Semarang seperti Karakteristik Penghuni yang memiliki kepadatan penduduk tinggi, karakteristik hunian yang memiliki bangunan yang beragam, karakteristik sarana dan prasarana yang memiliki kondisi masih kurang serta karakteristik lingkungan yang memiliki kondisi kurang terawat. Untuk tingkat kekumuhan, Kampung Pekojan Semarang memiliki tingkat kekumuhan sedang.

\section{E. DAFTAR RUJUKAN}

[1] Anonim. (2011). Bangunan Arsitektur Cina. Retrieved 2013, from http://www. architecture.uii.ac.id

[2] Architecture, W. (n.d.). Essential Architecture. Retrieved 2013, from http://www.essential-architecture.com/

[3] Damayanti, R. (2011). Teori Klasik Arsitektur Kota. Retrieved Oktober 2013, from http://rullydamayanti.wordpress.com

[4] Pigawati, R. N. 2015. Kajian Karakteristik Kawasan Pemukiman Kumuh Di Kampung Kota (Studi Kasus : Kampung Gandekan Semarang). Jurnal Teknik Pwk Volume 4 Nomor 2,15 .

[5] Putra, B. A. (2013). The Survival Phenomenon of Kampong Kuningan Amidst The Development of Mega Kuningan Business-area in Jakarta . International Journal of Scientific \& Engineering Research Volume 4, 1-6.

[6] Soetomo, Sugiono. 2002. Dari Urbanisasi Ke Morfologi Kota. Semarang: Badan Penerbit Universitas Diponegoro

[7] Undang-Undang Republik Indonesia Nomor 1 Tahun 2011 Tentang Perumahan Dan Kawasan Permukiman

[8] Wiryomartono, A. Bagoes. 1993. Seni Bangunan Dan Seni Binakota Di Indonesia. Jakarta: Pt. Gramedia Pustaka Utama.

[9] W BIBLIOGRAPHY ikipedia. (2013). Kota Semarang. Retrieved from http://id.wikipedia.org 